\title{
Glucose-induced beta cell dysfunction in vivo in rats: link between oxidative stress and endoplasmic reticulum stress
}

\author{
C. Tang • K. Koulajian • I. Schuiki • L. Zhang • \\ T. Desai • A. Ivovic $\cdot$ P. Wang $\cdot$ C. Robson-Doucette • \\ M. B. Wheeler • B. Minassian • A. Volchuk • A. Giacca
}

Received: 29 July 2011 / Accepted: 7 December 2011 / Published online: 1 March 2012

(C) Springer-Verlag 2012

\begin{abstract}
Aims/hypothesis Endoplasmic reticulum (ER) stress has been implicated in glucose-induced beta cell dysfunction. However, its causal role has not been established in vivo. Our objective was to determine the causal role of ER stress and its link to oxidative stress in glucose-induced beta cell dysfunction in vivo. Methods Healthy Wistar rats were infused i.v. with glucose for $48 \mathrm{~h}$ to achieve $20 \mathrm{mmol} / \mathrm{l}$ hyperglycaemia with or without the co-infusion of the superoxide dismutase mimetic tempol (TPO), or the chemical chaperones 4-phenylbutyrate (PBA) or tauroursodeoxycholic acid (TUDCA). This was followed by assessment of beta cell function and measurement of ER stress markers and superoxide in islets.

Results Glucose infusion for $48 \mathrm{~h}$ increased mitochondrial superoxide and ER stress markers and impaired beta cell function. Co-infusion of TPO, which we previously found to reduce mitochondrial superoxide and prevent glucoseinduced beta cell dysfunction, reduced ER stress markers.
\end{abstract}

Electronic supplementary material The online version of this article (doi:10.1007/s00125-012-2474-8) contains peer-reviewed but unedited supplementary material, which is available to authorised users.

C. Tang $\cdot$ K. Koulajian $\cdot$ T. Desai $\cdot$ A. Ivovic $\cdot$

C. Robson-Doucette $\cdot$ M. B. Wheeler $\cdot$ A. Giacca $(\square)$

Department of Physiology, University of Toronto,

Medical Science Building, Room 3336, 1 King's College Circle,

Toronto, ON, Canada M5S 1A8

e-mail: adria.giacca@utoronto.ca

I. Schuiki $\cdot$ L. Zhang $\cdot$ A. Volchuk

Division of Cellular and Molecular Biology,

Toronto General Research Institute, University Health Network,

Toronto, ON, Canada

P. Wang $\cdot$ B. Minassian

Program in Genetics and Genome Biology,

The Hospital for Sick Children,

Toronto, ON, Canada
Similar to findings with TPO, co-infusion of PBA, which decreases mitochondrial superoxide, prevented glucoseinduced beta cell dysfunction in isolated islets. TUDCA was also effective. Also similar to findings with TPO, PBA prevented beta cell dysfunction during hyperglycaemic clamps in vivo and after hyperglycaemia $(15 \mathrm{mmol} / \mathrm{l})$ for $96 \mathrm{~h}$.

Conclusions/interpretation Here, we causally implicate ER stress in hyperglycaemia-induced beta cell dysfunction in vivo. We show that: (1) there is a positive feedback cycle between oxidative stress and ER stress in glucose-induced beta cell dysfunction, which involves mitochondrial superoxide; and (2) this cycle can be interrupted by superoxide dismutase mimetics as well as chemical chaperones, which are of potential interest to preserve beta cell function in type 2 diabetes.

Keywords Beta cell dysfunction - Endoplasmic reticulum stress · Glucotoxicity · In vivo · Oxidative stress

\begin{tabular}{|c|c|}
\hline \multicolumn{2}{|c|}{ Abbreviations } \\
\hline ATF-6 & Activating transcription factor 6 \\
\hline $\mathrm{CHOP}$ & c/EBP-homologous protein 10 \\
\hline DI & Disposition index \\
\hline $\mathrm{eIF} 2 \alpha$ & Eukaryotic initiation factor- $2 \alpha$ \\
\hline ER & Endoplasmic reticulum \\
\hline Ginf & Glucose infusion rate \\
\hline GRP78 & $78 \mathrm{kDa}$ glucose-regulated protein \\
\hline GRP94 & $94 \mathrm{kDa}$ glucose-regulated protein \\
\hline HG & High glucose \\
\hline IRE-1 & Inositol-requiring protein-1 \\
\hline ISR & Integrated stress response \\
\hline $\mathrm{KRBH}$ & $\begin{array}{l}\text { Krebs-Ringer buffer containing } \\
10 \mathrm{mmol} / 1 \mathrm{HEPES}\end{array}$ \\
\hline PBA & 4-Phenylbutyrate \\
\hline PERK & $\begin{array}{l}\text { Protein kinase RNA-like endoplasmic } \\
\text { reticulum kinase }\end{array}$ \\
\hline
\end{tabular}

Abbreviations

ATF-6 Activating transcription factor 6

CHOP c/EBP-homologous protein 10

DI

Disposition index

Eukaryotic initiation factor- $2 \alpha$

Ginf

Glucose infusion rate

$78 \mathrm{kDa}$ glucose-regulated protein

GRP94 $94 \mathrm{kDa}$ glucose-regulated protein

HG

ISR Inositol-requiring protein-1

钐 Springer 
SAL Saline $(154 \mathrm{mmol} / \mathrm{l} \mathrm{NaCl})$ control

sXbpl Spliced Xbpl

TPO Tempol

TUDCA Tauroursodeoxycholic acid

UPR Unfolded protein response

uXbpl Unspliced Xbpl

\section{Introduction}

Type 2 diabetes is characterised by insulin resistance and a defect in insulin secretion, which is inadequate to compensate for insulin resistance (relative insulin deficiency). The progressive failure of beta cells to secrete enough insulin to compensate for insulin resistance leads to hyperglycaemia, which in turn exerts deleterious effects on beta cells [1].

One proposed mechanism of glucose-induced beta cell dysfunction is endoplasmic reticulum (ER) stress [2]. Prolonged in vitro exposure of beta cell lines or islets to glucose increased ER stress markers in the majority of studies [3-8], and overproduction of the ER chaperone $78 \mathrm{kDa}$ glucoseregulated protein (GRP78) partially prevented glucoseinduced beta cell dysfunction in vitro in INS-1 cells [9]. However, it is currently unknown whether ER stress plays a causal role in glucose-induced beta cell dysfunction in vivo.

Oxidative stress plays a causal role in glucose-induced beta cell dysfunction both in vitro and in vivo $[1,10]$. Both ER stress [11] and oxidative stress [12] are increased in islets of individuals with type 2 diabetes. Recent studies demonstrate a close inter-relationship between oxidative stress and ER stress in beta cells $[13,14]$. Oxidative stress can induce ER stress, and vice versa [2]. However, it is not known whether there is a causal link between oxidative stress and ER stress in the context of glucose-induced beta cell dysfunction.

Previously, we have demonstrated that glucose infusion over $48 \mathrm{~h}$ in rats increases reactive oxygen species, and that co-infusion of the superoxide dismutase mimetic tempol (TPO), prevents glucose-induced beta cell dysfunction in vivo [10]. The objectives of this study were: (1) to investigate whether ER stress plays a causal role in glucoseinduced beta cell dysfunction in vivo; and (2) to determine whether there is a link between ER stress and oxidative stress in glucose-induced beta cell dysfunction.

\section{Methods}

Animals and surgery

Female Wistar rats (Charles River, Senneville, QC, Canada) received vessel cannulation of the carotid artery (for sampling) and jugular vein (for infusion) [10]. All procedures were approved by the animal care committee at the
University of Toronto. Rats were allowed a minimum of 3 days between surgery and i.v. infusions.

Forty-eight hour infusions

Studies with TPO Rats were infused i.v. for $48 \mathrm{~h}$ with one of: (1) $\mathrm{NaCl}$ (154 mmol/l) (SAL); (2) a variable infusion of high glucose (HG; $37.5 \% \mathrm{wt} / \mathrm{vol}$.) to maintain plasma glucose at 20-22 mmol/l; (3) HG + TPO (Sigma, St Louis, MO, USA; $2.41 \mu \mathrm{mol} \mathrm{kg}^{-1} \mathrm{~min}^{-1}$ ); or (4) TPO as in Tang et al. [10]. TPO was dissolved in $\mathrm{NaCl}, \mathrm{pH}$ 7.4. Following overnight fasting and immediately after $48 \mathrm{~h}$ infusion, islets were isolated to perform the insulin secretion studies described in Tang et al. [10]. In the present manuscript, we report findings for the ER stress markers. Pancreas tissue (collected after the hyperglycaemic clamps described in Tang et al. [10]) was fixed for immunohistochemistry.

Studies with 4-phenylbutyrate Rats were infused i.v. for $48 \mathrm{~h}$ with one of: (1) SAL; (2) HG as above; (3) HG+4phenylbutyric acid (PBA [Sigma]; $2.08 \mu \mathrm{mol} \mathrm{kg}{ }^{-1} \mathrm{~min}^{-1}$ ) [15]; or (4) PBA. PBA was dissolved in $\mathrm{NaCl}, \mathrm{pH}$ 7.4. PBA acts as a chemical chaperone to improve protein folding [16]. Following overnight fasting and immediately after $48 \mathrm{~h}$ infusion, we carried out one of the following protocols: (1) insulin secretory studies, superoxide measurements (total and mitochondrial), and ER-stress-marker detection in isolated islets (ex vivo studies in islets); or (2) two-step hyperglycaemic clamps followed by pancreas collection for immunohistochemistry.

Studies with tauroursodeoxycholic acid Rats were infused i.v. for $48 \mathrm{~h}$ with one of: (1) SAL; (2) HG as above; (3) HG + tauroursodeoxycholic acid (TUDCA; Sigma), which also acts as a chemical chaperone [16], at a dose of $2 \mu \mathrm{mol} \mathrm{kg}^{-1} \mathrm{~min}^{-1}$ [17]; and (4) TUDCA. TUDCA was dissolved in $\mathrm{NaCl}$, $\mathrm{pH}$ 7.4. Islets were isolated for ex vivo studies.

Ex vivo studies in islets

Pancreatic islets were isolated with collagenase (Sigma) [10], pre-incubated in Krebs-Ringer buffer containing 10 mmol/1 HEPES (KRBH; Wisent, St. Bruno, QC, Canada) and $2.8 \mathrm{mmol} / 1$ glucose for $1 \mathrm{~h}$, and then incubated for $2 \mathrm{~h}$ at different glucose concentrations. Insulin was measured in the supernatant fraction with Linco's RIA kit (St Charles, MO, USA). The islets used for secretion study were then subjected to acid ethanol extraction [10] for insulin and proinsulin content measurement via RIA and ELISA (ALPCO Diagnostics, Salem, NH, USA), respectively. Total and mitochondrial superoxide were measured as in Tang et al. [10]. Total RNA was extracted from isolated islets using Trizol Reagent (Invitrogen, Burlington, ON, Canada). RNA 
was reverse transcribed into single-stranded cDNA, which was used for real-time PCR analysis using the TaqMan Gene Expression System (Applied Biosystems, Foster City, CA, USA) [9]. Primers for Grp78 (also known as Hspa5; Rn01435771_g1), Chop (also known as Ddit3; Rn00492098 g1), and rat Ins 2 (Rn01774648g 1) were obtained from Applied Biosystems. Spliced Xbpl (s $X b p 1$ ) mRNA was detected as in Zhang et al. [9]. Western blots were performed as in Zhang et al. [9]. The following primary antibodies were used: phospho-eukaryotic initiation factor- $2 \alpha$ (eIF $2 \alpha)$ (Cell Signaling, Danvers, MA, USA; \#9721; 1:500); total eIF2 $\alpha$ (Cell Signaling; \#9722; 1:1,000); anti-KDEL (amino acid sequence: $\mathrm{K}$, lysine; D, aspartic acid; E, glutamic acid; L, leucine [Stressgen, Brussels, Belgium; SPA-827; $1: 1,000]$ ); and $\gamma$-tubulin (Sigma; T6557; 1:1,000).

Two-step hyperglycaemic clamp

Insulin secretion was determined by measuring plasma insulin and C-peptide during a two-step (13 and $22 \mathrm{mmol} / \mathrm{l}$ ) hyperglycaemic clamp in conscious rats after infusion for $48 \mathrm{~h}$ with one of: (1) SAL; (2) HG; (3) HG + PBA; and (4) PBA alone (as described above). The clamp details have been previously reported [10] and the evaluation of insulin sensitivity and beta cell function are presented in the electronic supplementary material (ESM Methods).

Immunohistochemistry

At the end of the hyperglycaemic clamp, pancreas was collected [10] and immunostained [18]. The primary antibodies used were mouse monoclonal anti-KDEL (Stressgen; \#SPA-827; 1:200), rabbit polyclonal anti-ubiquitin antibody (Dako, Burlington, ON, Canada, Z0458; 1:100) and guinea pig anti-insulin antibody (Dako; Z0564; 1:200). Secondary antibodies used were Oregon Green goat anti-mouse or antirabbit IgG (Invitrogen; O11033), Oregon Green goat-anti rabbit IgG (Invitrogen; O11038) and Cy5-conjugated donkey anti-guinea pig IgG (Jackson ImmunoResearch Laboratories, West Grove, PA, USA; \#706-175-148; 1:200). Images were acquired using a Zeiss LSM510 META laser scanning confocal microscope.

Plasma assays

Linco's RIA kits specific for rat insulin and C-peptide were used.

Ninety-six hour infusions

A set of rats were also infused for $96 \mathrm{~h}$ with one of: (1) SAL; (2) a variable infusion of $\mathrm{HG}(37.5 \%$ glucose) to achieve and maintain plasma glucose at $15 \mathrm{mmol} / \mathrm{l}$; (3) HG + PBA; or (4)
PBA alone. The same dose of PBA was used as in the $48 \mathrm{~h}$ infusion study. Following the $96 \mathrm{~h}$ infusion, islets were isolated for ex vivo studies, which were performed as described above.

INS- 1 cells

INS-1 cells were obtained from C. Wollheim (University of Geneva, Switzerland) and cultured as in Asfari et al. [19]. The cells were used within the first few passages upon thawing. INS-1 cells were treated with $1 \mu \mathrm{mol} / 1$ thapsigargin (Sigma; T9033) as a positive control for the induction of ER stress markers.

Statistical analysis

Data are presented as means \pm SE. One-way non-parametric ANOVA for repeated measurements was used followed by Tukey's $t$ test. Calculations were performed using SAS (Cary, NC, USA).

\section{Results}

A hyperglycaemic environment for $48 \mathrm{~h}$ induces activation of the unfolded protein response in an oxidative-stressdependent manner

We previously reported that hyperglycaemia for $48 \mathrm{~h}$ increased total and mitochondrial superoxide and decreased beta cell function in isolated islets and during hyperglycaemic clamps in vivo, and that this effect was prevented by the antioxidant TPO (a known superoxide mimetic) [10]. To address the link between hyperglycaemia, oxidative stress and ER stress, we measured the ER stress markers.

ER stress activates three sensor proteins, protein kinase RNA-like ER kinase (PERK), inositol-requiring protein-1 (IRE-1) and activating transcription factor 6 (ATF-6), which mediate the unfolded protein response (UPR) [2]. Activated PERK phosphorylates eIF $2 \alpha$, which attenuates general protein translation. As shown in Fig. 1a,b, hyperglycaemia increased phospho-eIF $2 \alpha$, and co-infusion of TPO completely prevented this effect. TPO alone did not affect phospho-eIF $2 \alpha$. As expected, total eIF $2 \alpha$ was not affected by treatment (ESM Fig. 1).

Activated IRE-1 results in splicing of Xbpl mRNA, which leads to enhanced $X b p 1$ translation. Hyperglycaemia increased Xbp1 mRNA splicing, and co-infusion of TPO partially prevented this effect. TPO alone mildly increased sXbp1 mRNA (Fig. 1c,d).

Activation of the UPR leads to increased expression of the pro-apoptotic factor c/EBP-homologous protein 10 (CHOP) and ER chaperones such as GRP78 and $94 \mathrm{kDa}$ glucose-regulated protein (GRP94) [20, 21]. Glucose 

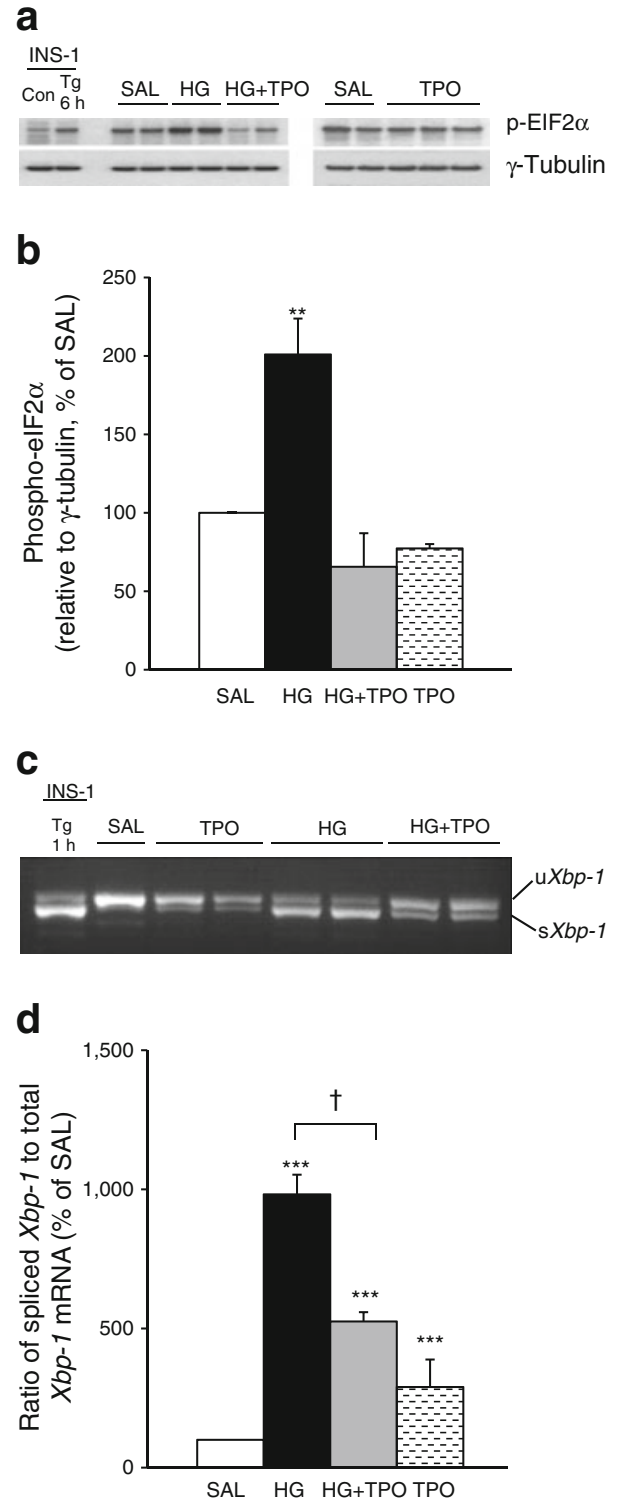

Fig. 1 Hyperglycaemia for $48 \mathrm{~h}$ induces activation of the UPR in rat islets in an oxidative-stress-dependent manner. Rats were treated for $48 \mathrm{~h}$, as previously described [10], with: SAL; HG to maintain glycaemia at $\sim 20-22 \mathrm{mmol} / \mathrm{l} ; \mathrm{HG}+\mathrm{TPO}, 2.41 \mu \mathrm{mol} \mathrm{kg}^{-1} \mathrm{~min}^{-1}$; or TPO, $2.41 \mu \mathrm{mol} \mathrm{kg} \mathrm{min}^{-1}$. a Representative immunoblots of phosphoeIF $2 \alpha$. Each lane represents islet lysates from one animal. As a positive control, cultured INS-1 cells were treated or not with thapsigargin for $6 \mathrm{~h}$. b Western blots for phospho-eIF $2 \alpha$ were quantified and results, normalised by $\gamma$-tubulin, are expressed as $\%$ of SAL (SAL, $n=5$; HG, $n=7 ; \mathrm{HG}+\mathrm{TPO}, n=5$; TPO, $n=3)$. c Xbpl mRNA was reverse

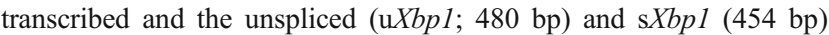
forms of $X b p 1 \mathrm{cDNA}$ were amplified by real-time PCR using primers that flank the intron excised by IRE-1 endoribonuclease activity. Each lane represents islet lysates from one animal. As a positive control, cultured INS-1 cells were treated with thapsigargin for $1 \mathrm{~h}$. d The mean of the ratio of $\mathrm{s} X b p 1$ to total $X b p 1$ mRNA (as a \% of SAL; SAL, $n=7$; HG, $n=7$; HG + TPO, $n=4$; TPO, $\mathrm{n}=4)$. Data are means \pm SE. ${ }^{* *} p<0.01$ and ${ }^{* * *} p<0.001$ vs SAL; ${ }^{\dagger} p<0.05 \mathrm{HG}+\mathrm{TPO}$ vs HG. Con, control; Tg, thapsigargin infusion over $48 \mathrm{~h}$ increased Chop and Grp 78 mRNA. Coinfusion of TPO prevented the high glucose-induced upregulation of Chop mRNA, but not Grp78 mRNA. TPO alone did not affect Grp78 or Chop mRNA (Fig. 2a,b).

Exposure to glucose infusion for $48 \mathrm{~h}$ also increased the protein levels of GRP78 and GRP94 (Fig. 2c-e). Coinfusion of TPO did not decrease GRP78 protein and even tended to increase GRP94 protein $(p<0.2)$. TPO alone had no effect (Fig. 2c-e). Consistent with the results of the western blot analysis, pancreas sections immunostained with $\alpha$-KDEL antibody, which recognises GRP78 and GRP94, showed a more intense staining in islets exposed to hyperglycaemia compared with control islets (Fig. 3a,b), while co-infusion of TPO did not decrease $\alpha$-KDEL staining (Fig. 3c).

The chemical chaperone PBA prevents glucose-induced beta cell dysfunction ex vivo

As $48 \mathrm{~h}$ hyperglycaemia induced activation of the UPR, we infused PBA, a chemical chaperone, to determine whether it could restore beta cell function in the presence of hyperglycaemia. Following $48 \mathrm{~h} \mathrm{SAL} / \mathrm{HG}$ infusion $\pm \mathrm{PBA}$, islets were isolated and insulin secretion was measured. Insulin secretion at $2.8 \mathrm{mmol} / \mathrm{l}$ glucose did not differ between groups (Fig. 4a). Glucose infusion over $48 \mathrm{~h}$ increased insulin secretion at $6.5 \mathrm{mmol} / \mathrm{l}$, but impaired insulin secretion at 13 and $22 \mathrm{mmol} / \mathrm{l}$ glucose. Co-infusion of PBA with glucose did not significantly affect insulin secretion at $6.5 \mathrm{mmol} / \mathrm{l}$ glucose, but completely restored insulin secretion at 13 and $22 \mathrm{mmol} / \mathrm{l}$ glucose (Fig. 4a). Glucose infusion over $48 \mathrm{~h}$ reduced islet insulin content and this was not improved by co-infusion of PBA (Fig. 4b). Glucose infusion for $48 \mathrm{~h}$ did not reduce proinsulin content (indicating that insulin content decreased because of previous hypersecretion), and proinsulin content was not significantly affected by PBA (Fig. 4c).

PBA decreases activation of IRE-1 but not the PERK pathway

To investigate the effect of PBA on activation of UPR, the PERK and IRE-1 pathways were monitored. As shown in Fig. 4d,e, co-infusion of PBA with glucose did not decrease glucose-induced phospho-eIF $2 \alpha$. However, PBA coinfusion reduced sXbp1 mRNA (Fig. 4f, g), suggesting that PBA decreases activation of IRE-1. Unexpectedly, PBA alone increased phospho-eIF $2 \alpha$ and slightly elevated $\mathrm{s} X b p 1$ mRNA.

Co-infusion of PBA partially decreased Chop and Grp 78 mRNA induced by $48 \mathrm{~h}$ glucose infusion (Fig. 5a,b). Similar to TPO, co-infusion of PBA did not decrease GRP78 protein, and significantly increased GRP94 compared with 
Fig. 2 Effects of

hyperglycaemia and TPO on markers downstream of UPR activation. Total RNA was extracted from islets isolated from rats treated as described in the legend of Fig. 1. Real-time RT-PCR was used to analyse the relative mRNA levels of Chop (a) and Grp78 (b).

Results are expressed as target gene relative to $\beta$-actin ( $n=4$ rats per group). c Representative immunoblots with the $\alpha$ KDEL antibody that recognises GRP78 and GRP94 as indicated. Each lane represents islet lysates from one animal. Western blots for GRP94 (d) and GRP78 (e) were quantified and results are expressed as \% of SAL normalised by $\gamma$-tubulin (SAL, $n=9$; HG, $n=10$; HG + TPO, $n=5$; TPO, $n=3$ ). Data are means \pm SE. $* * p<0.01$ and $* * * p<0.001$ vs SAL a

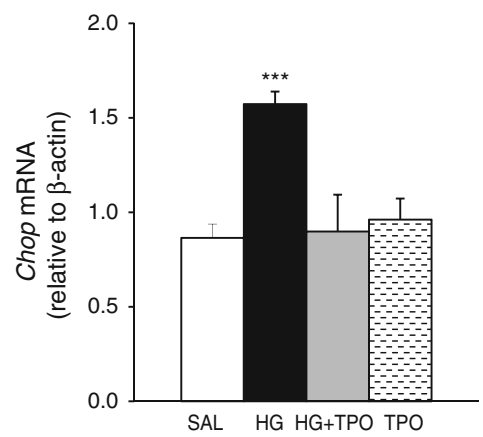

b

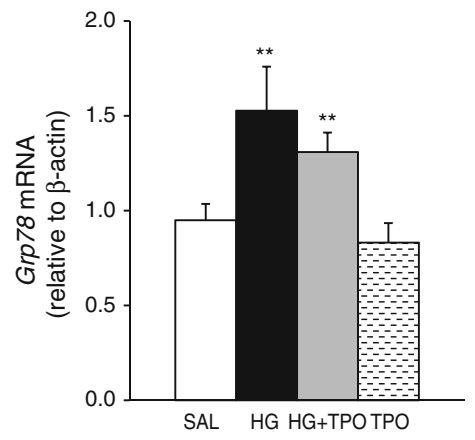

C

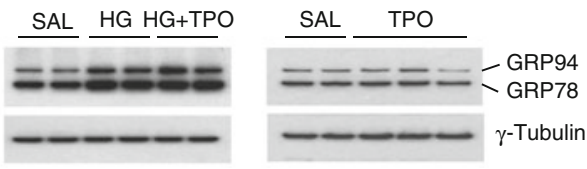

d

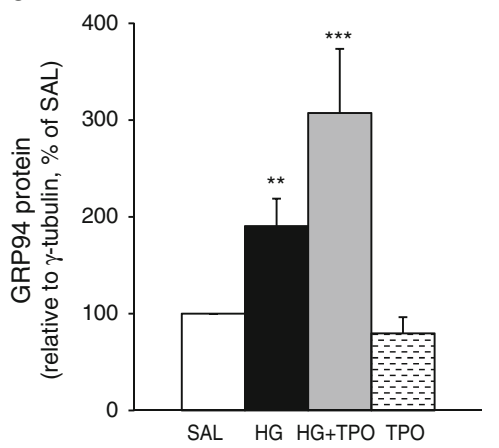

e

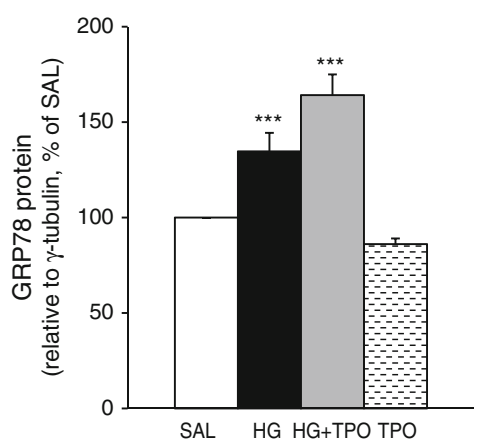

glucose infusion alone (Fig. 5c-e). PBA alone slightly increased Chop and Grp78 mRNA, and GRP78 and GRP94 protein levels compared with control. Consistent with our western blot data, immunostaining for $\alpha$-KDEL showed greater staining in the glucose-infused groups compared with control, irrespective of PBA (Fig. 3b,d).

PBA reduces total and mitochondrial superoxide

Glucose infusion for $48 \mathrm{~h}$ elevated total and mitochondrial islet superoxide, as previously reported [10]. Co-infusion of PBA with glucose significantly lowered both total and mitochondrial superoxide. PBA alone reduced total superoxide, but did not affect mitochondrial superoxide (Fig. 6).

TUDCA, another chemical chaperone, also prevents glucose-induced beta cell dysfunction ex vivo

As PBA may have non-specific effects, including the inhibition of histone deacetylation [15], we performed experiments with TUDCA, another chemical chaperone. Similar to findings with PBA, co-infusion of TUDCA - which decreased hyperglycaemia-induced $X b p 1$ mRNA splicing and Chop mRNA (ESM Fig. 2a,b) — did not alter the effect of hyperglycaemia on insulin secretion at $6.5 \mathrm{mmol} / \mathrm{l}$ glucose, but completely restored insulin secretion at 13 and $22 \mathrm{mmol} / \mathrm{l}$ glucose (Fig. 7a). Also similar to PBA, TUDCA did not improve islet insulin or proinsulin content (Fig. 7b, c).

PBA prevents glucose-induced beta cell dysfunction in vivo

To investigate whether PBA is effective in preventing glucose-induced beta cell dysfunction in vivo, a two-step hyperglycaemic clamp was performed, as with our studies with TPO [10]. Basal plasma glucose before the clamp was lower in the groups previously infused with glucose (HG and $\mathrm{HG}+\mathrm{PBA}$ ). Plasma glucose was elevated to $13 \mathrm{mmol} / \mathrm{l}$ and then to $22 \mathrm{mmol} / \mathrm{l}$, with no difference between groups (Fig. 8a).

In the HG group, a lower glucose infusion rate (Ginf) was necessary to clamp glucose at $22 \mathrm{mmol} / \mathrm{l}$, indicating that the circulating insulin was inadequate to compensate for insulin resistance. Co-infusion of PBA completely normalised Ginf (Fig. 8b).

Basal insulin and C-peptide levels were higher in the groups previously infused with glucose (HG and $\mathrm{HG}+$ PBA) (Fig. 8c,d). During the hyperglycaemic clamps, in response to increasing glucose levels, plasma insulin and 
Fig. 3 Effects of TPO and PBA on GRP78 and GRP94 levels in pancreatic tissue sections at the end of $48 \mathrm{~h}$ glucose infusion. Pancreatic tissue sections obtained from rats treated as described in the legends of Figs 1 and 4. Sections were co-stained with $\alpha$-KDEL (green) and $\alpha$-insulin (red) antibodies and images were obtained using a laser scanning confocal microscope. a SAL; b HG; c HG + TPO; d $\mathrm{HG}+\mathrm{PBA}$; e TPO; and f PBA. Increased staining with the $\alpha$-KDEL antibody in HG pancreas was also evident in the surrounding acinar cells, perhaps indicative of some ER stress occurring in these cells. This is consistent with our previous findings [18] a

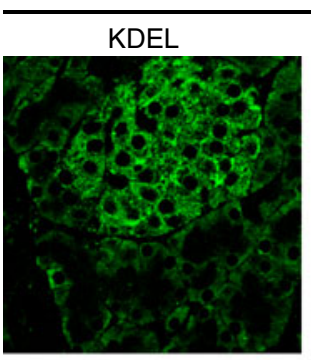

SAL

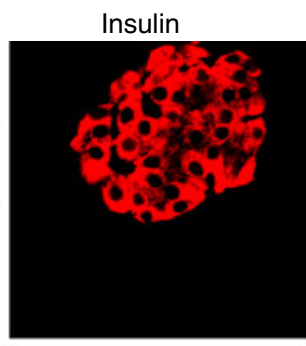

C

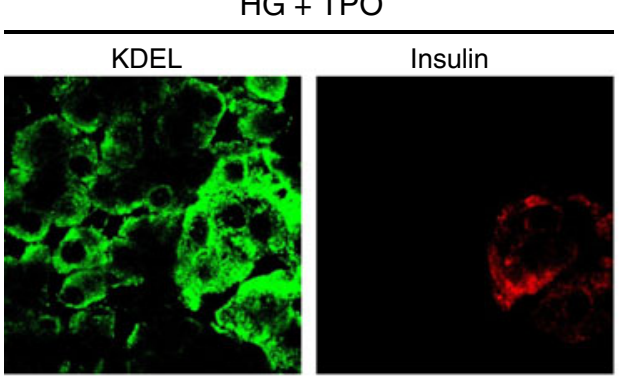

e

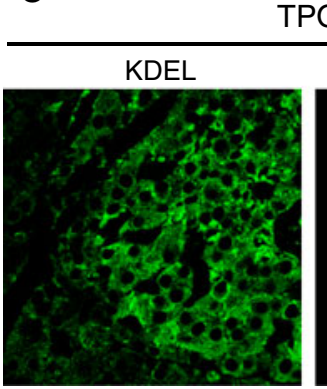

b

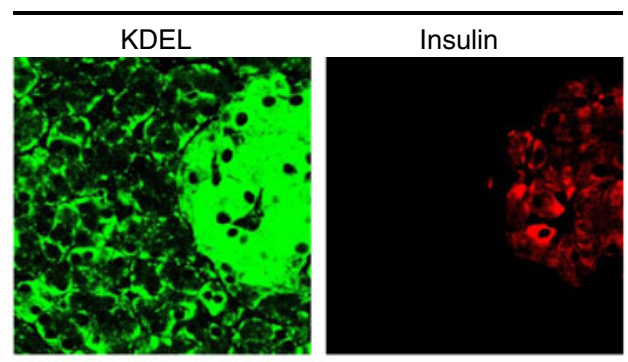

d

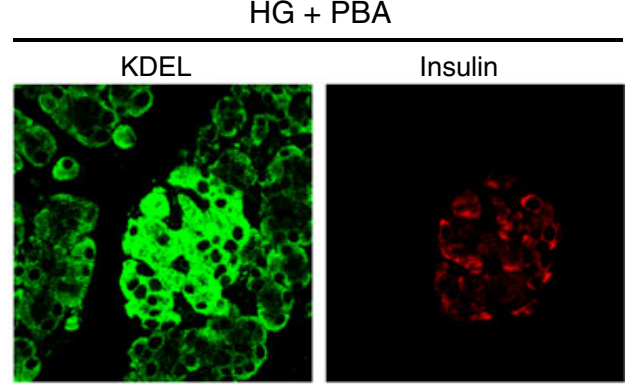

f

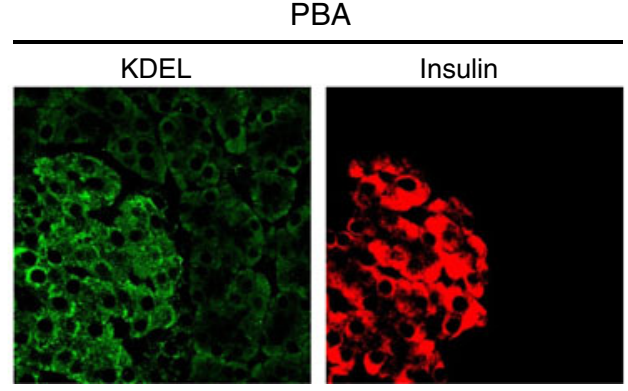

C-peptide levels rose as expected. The HG group had elevated plasma insulin at both $13 \mathrm{mmol} / \mathrm{l}$ and $22 \mathrm{mmol} / \mathrm{l}$ glucose, and C-peptide at $13 \mathrm{mmol} / \mathrm{l}$ glucose. Compared with the $\mathrm{HG}$ group, the $\mathrm{HG}+\mathrm{PBA}$ group tended to show lower plasma insulin, but higher C-peptide levels, at $22 \mathrm{mmol} / 1$ (Fig. 8c,d).

The C-peptide/insulin ratio (index of insulin clearance) was lower with $\mathrm{HG}$ than with SAL at $13 \mathrm{mmol} / \mathrm{l}(p<0.05 \mathrm{vs} \mathrm{SAL}$; $\mathrm{SAL}=3.66 \pm 0.26 \mathrm{vs} \mathrm{HG}=2.11 \pm 0.09)$ and $22 \mathrm{mmol} / 1$ glucose $(p<0.05$ vs $\mathrm{SAL} ; \mathrm{SAL}=3.08 \pm 0.20$ vs $\mathrm{HG}=2.10 \pm 0.09)$. The decrease in the $\mathrm{C}$-peptide/insulin ratio was partially prevented by the co-infusion of PBA $(\mathrm{HG}+\mathrm{PBA}=2.56 \pm 0.17$ at $13 \mathrm{mmol} / 1$ glucose; $2.51 \pm 0.21$; NS vs SAL or HG at both glucose levels). Sensitivity index (M/I index: glucose metabolism (M), which is represented by Ginf, divided by plasma insulin (I); see ESM Methods for calculation) was decreased in HG compared with SAL at both 13 and $22 \mathrm{mmol} / 1$ glucose. Co-infusion of PBA tended to prevent this decrease (Fig. 8e).

Although insulin and C-peptide levels were elevated in $\mathrm{HG}$, the disposition index (DI), which takes into account the ability of the beta cell to compensate for insulin resistance (see ESM Methods for a description of DI), was lower with HG than with SAL. PBA completely normalised DI during both steps of the clamp (Fig. 8f).

PBA prevents beta cell dysfunction in a more chronic, milder model of hyperglycaemia

As in our previous study with TPO, we also investigated the effect of PBA in a less extreme, more prolonged model of hyperglycaemia. Previous hyperglycaemia at $15 \mathrm{mmol} / \mathrm{l}$ for $96 \mathrm{~h}$ increased insulin secretion at 2.8 and $6.5 \mathrm{mmol} / \mathrm{l}$ glucose, but impaired insulin secretion at 13 and $22 \mathrm{mmol} / \mathrm{l} \mathrm{glu}-$ cose. Similar to the effect of TPO seen previously [10], PBA did not prevent the increase in insulin secretion at 2.8 and $6.5 \mathrm{mmol} / \mathrm{l}$ induced by hyperglycaemia, but prevented the impairment in insulin secretion at 13 and $22 \mathrm{mmol} / 1$ glucose (Fig. 9a). Islet insulin content was reduced by $96 \mathrm{~h}$ of hyperglycaemia. This was partially prevented by PBA co-infusion (Fig. 9b). Hyperglycaemia for $96 \mathrm{~h}$ did not decrease islet proinsulin content. However, co-infusion of PBA significantly elevated proinsulin content (Fig. 9c). Phospho-eIF2 $\alpha$ levels 

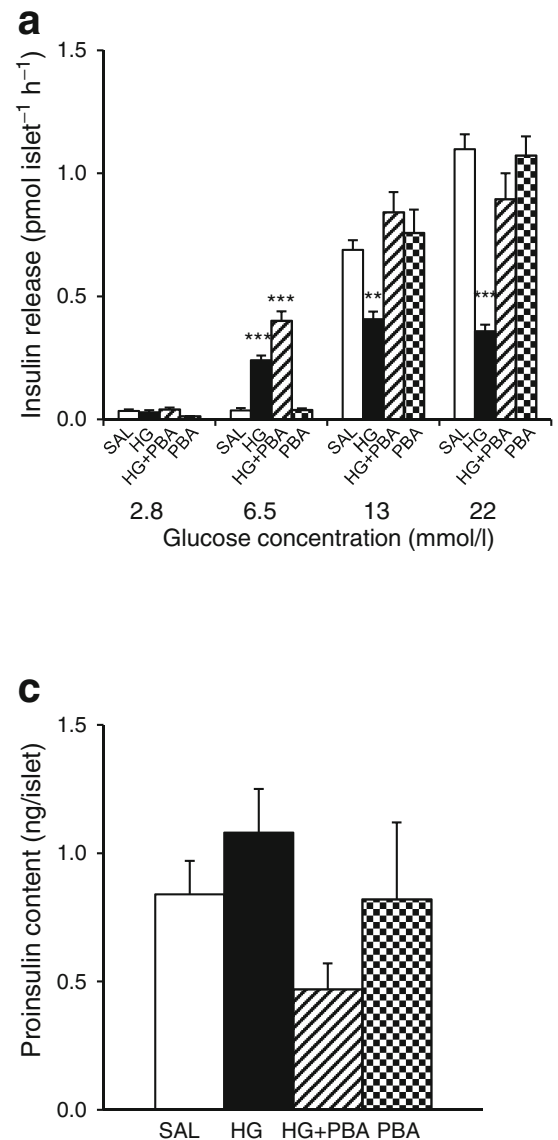

f

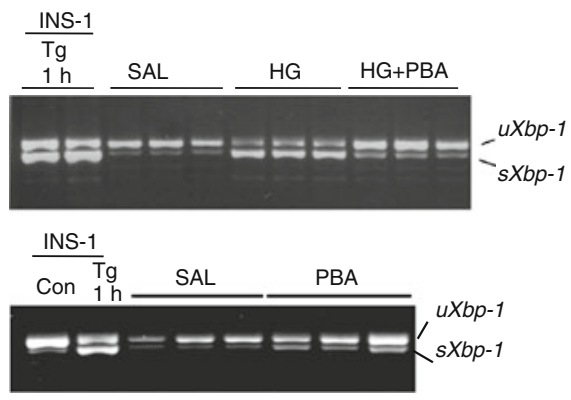

Fig. 4 PBA prevents glucose-induced beta cell dysfunction ex vivo, and decreases activation of the IRE-1 pathway. Rats were treated for 48 h with: SAL; HG; HG + PBA, $2.08 \mu \mathrm{mol} / \mathrm{kg}^{-1} \mathrm{~min}^{-1}$; or PBA, $2.08 \mu \mathrm{mol} \mathrm{kg}{ }^{-1} \mathrm{~min}^{-1}$. Following $48 \mathrm{~h}$ infusion, islets were isolated and pre-incubated in KRBH containing $2.8 \mathrm{mmol} / 1$ glucose for $1 \mathrm{~h}$ at $37^{\circ} \mathrm{C}$. Thereafter, five islets of approximately the same size were transferred in triplicate to vials containing fresh medium plus glucose at $2.8,6.5,13$ and $22 \mathrm{mmol} / 1$. Islets were incubated for $2 \mathrm{~h}$ at $37^{\circ} \mathrm{C}$, and the insulin released was measured in the supernatant fraction (SAL, $n=12$; HG, $n=12$; HG + PBA, $n=10$; PBA, $n=6$ ) (a). The islet pellets were subjected to acid-ethanol extraction for measurement of insulin content using RIA (SAL, $n=10$; HG, $n=11$; $\mathrm{HG}+\mathrm{PBA}, n=8$; PBA, $n=6$ ) (b) and proinsulin content using ELISA (SAL, $n=3$; HG, $n=3$; HG + PBA, $n=4$; PBA, $n=4)(\mathbf{c})$. d A representative immunoblot of

tended to be lower with hyperglycaemia and PBA alone. In the HG + PBA group, the decrease was significant vs control, b

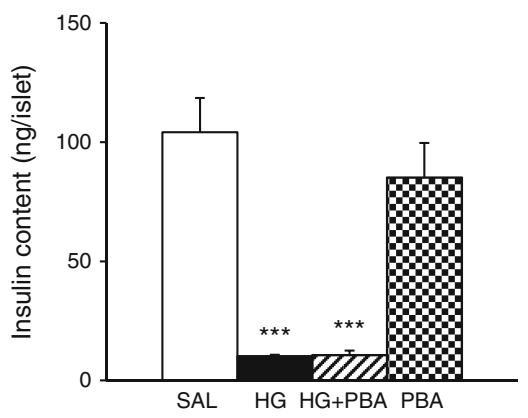

d

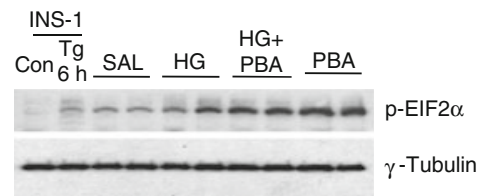

e

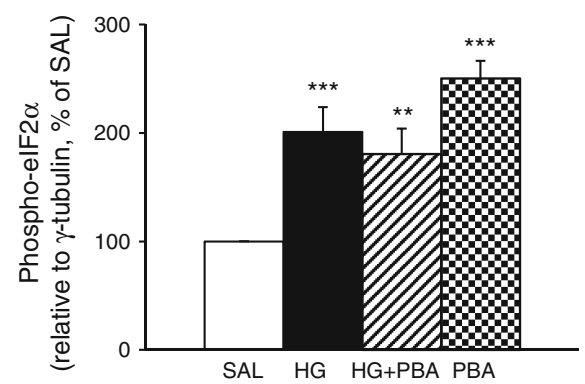

g

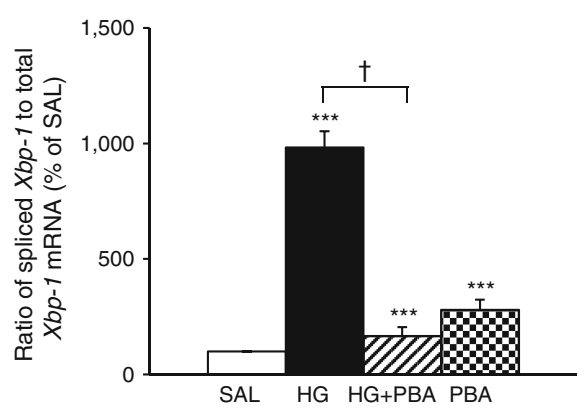

phospho-eIF $2 \alpha$. Each lane represents islet lysates from one animal. As a positive control, cultured INS-1 cells were treated or not treated with thapsigargin for $6 \mathrm{~h}$. Western blots for phospho-eIF $2 \alpha$ were quantified and the results normalised by $\gamma$-tubulin are expressed as \% of SAL (e) (SAL, $n=5$; HG, $n=7$; HG + PBA, $n=5$; PBA, $n=5$ ). f $X b p 1$ mRNA was reverse transcribed and $\mathrm{u} X b p 1$ and $\mathrm{s} X b p 1$ were amplified by realtime PCR using primers that flank the intron excised by IRE-1 endoribonuclease activity. Each lane represents islet lysates from one animal. As a positive control, cultured INS-1 cells were treated with thapsigargin for $1 \mathrm{~h}$ and two independent samples are shown. $\mathrm{g}$ The mean of the ratio of $\mathrm{s} X b p 1$ to total $X b p 1$ mRNA (as a \% of SAL; SAL, $n=7$; $\mathrm{HG}, n=7 ; \mathrm{HG}+\mathrm{PBA}, n=3$; PBA, $n=3)$. Data are means \pm SE. ${ }^{*} p<0.01$ and $* * * p<0.001$ vs SAL; ${ }^{\dagger} p<0.05 \mathrm{HG}+$ PBA vs HG. Con, control; Tg, thapsigargin

but not vs HG alone (Fig. 9d,e). Hyperglycaemia increased Xbpl mRNA splicing and PBA co-infusion decreased $\mathrm{s} X b p 1$ 
Fig. 5 Effects of

hyperglycaemia and PBA on markers downstream of UPR activation. Total RNA was isolated from islets isolated from rats treated as described in the legend of Fig. 4. Real-time RT-PCR was used to analyse the relative mRNA levels of Chop (a) and $\operatorname{Grp} 78$ (b). Results are expressed as target gene relative to $\beta$-actin ( $n=4$ rats per group). c A representative immunoblot with the $\alpha$-KDEL antibody that recognises GRP78 and GRP94. Each lane represents islet lysates from one animal. Western blots for GRP94 (d) and GRP78 (e) were quantified and results are expressed as $\%$ of SAL normalised by $\gamma$-tubulin (SAL, $n=9$; HG, $n=10$; HG + PBA, $n=5$; PBA, $n=5)$. Data are means \pm SE. $* p<0.05, * * p<0.01$ and $* * * p<0.001$ vs SAL; ${ }^{\dagger} p<0.01$ $\mathrm{HG}+\mathrm{PBA}$ vs HG

a

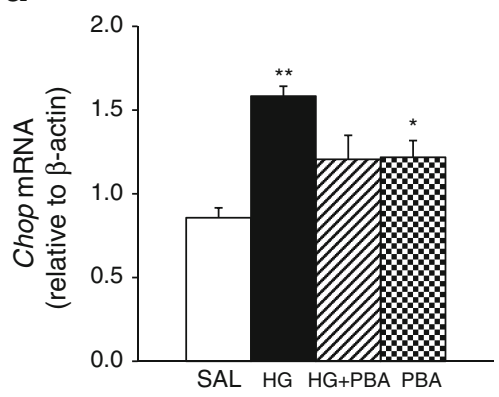

b

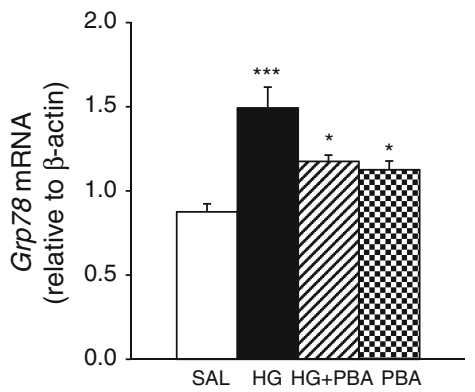

C

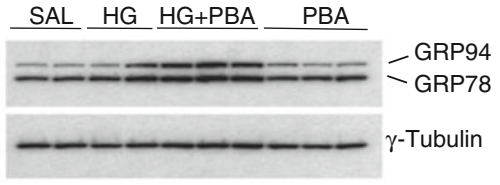

d

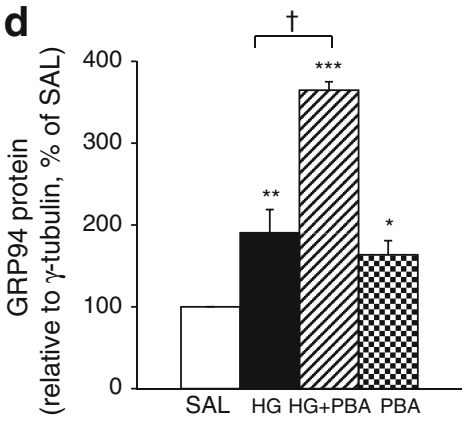

e

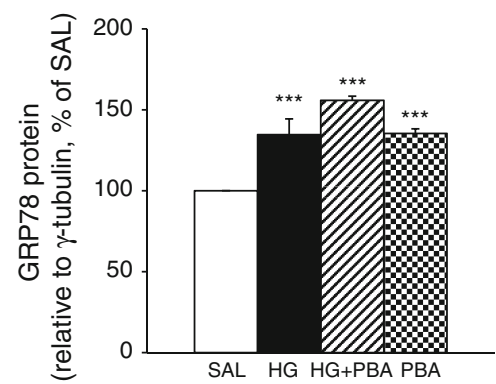

mRNA levels below those in the control (Fig. 9f,g). PBA alone decreased $\mathrm{s} X b p 1 \mathrm{mRNA}$, suggesting that, chronically, islets adapt to PBA so that the elevation of some ER stress markers observed at $48 \mathrm{~h}$ no longer persists. As Xbpl mRNA splicing in SAL was greater at 96 than $48 \mathrm{~h}$ (Fig. 9f vs Fig. 4f), another possibility is that PBA protected against this increase.

\section{Discussion}

We here show that in vivo islet exposure to $H G$ for $48 \mathrm{~h}$ increased activation of the UPR. Co-infusion of TPO decreased markers of UPR activation induced by glucose (phospho-eIF2 $\alpha$, sXbp1 mRNA and Chop mRNA). Our previous study shows that co-infusion of TPO with glucose decreases total and mitochondrial superoxide in islets [10]. A role of antioxidants in reducing ER stress to improve protein secretion has been documented in other cell types [22]. Recent studies demonstrate that the ER and mitochondria interact both spatially and functionally [23]. We hypothesise that an increase in mitochondrial superoxide production in the electron transport chain during hyperglycaemia may leak into the ER. This may impair protein folding [24] and deplete ER calcium by inhibiting sarcoplasmic reticulum ATPase [25, 26], leading to ER stress.
Thus, it is possible that TPO mitigates ER stress via reducing mitochondrial superoxide.

The observation that TPO prevents the glucose-induced increase in ER stress markers supports the notion that ER stress lies downstream of oxidative stress. However, there is also evidence that ER stress can induce oxidative stress [13, $14,27]$. In the present study, PBA reduced total and mitochondrial superoxide levels in islets, suggesting that ER stress may impair beta cell function by inducing oxidative stress. ER stress can increase superoxide via $\mathrm{Ca}^{2+}$ leakage from the ER, and uptake into mitochondria, which can subsequently cause disruption of the electron transport chain [28].

In the $48 \mathrm{~h}$ infusion model, co-infusion of PBA with glucose decreased Xbp1 mRNA splicing, and Chop mRNA, similar to TPO. Neither PBA nor TPO decreased GRP78 and GRP94 protein levels. GRP94 was actually increased by PBA and tended to be increased with TPO. The reason for this effect of PBA/TPO is unclear. However, it is possible that co-infusion of PBA/TPO results in a milder degree of ER stress than glucose infusion alone, which allows the beta cell to increase the production of chaperones [29]. Interestingly, TPO, but not PBA, prevented the glucose-induced increase in phospho-eIF $2 \alpha$. Also interestingly, after $96 \mathrm{~h}$ of $15 \mathrm{mmol} / \mathrm{l} \mathrm{HG}$, a milder model of hyperglycaemia, 
a

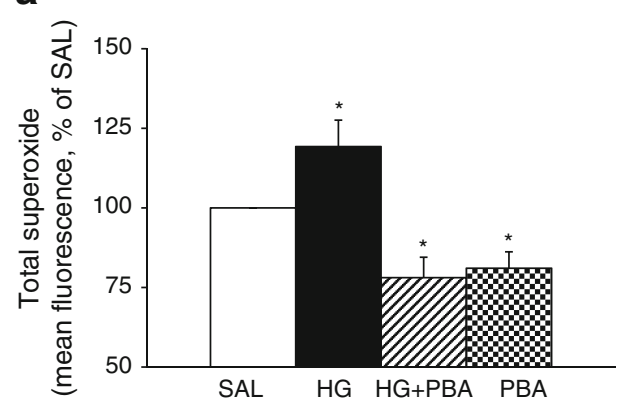

C

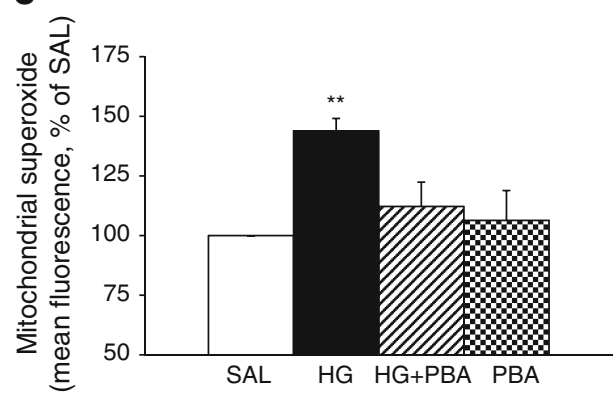

b

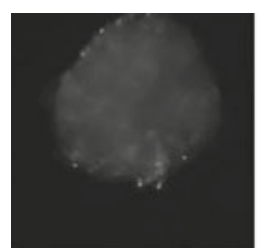

SAL

d

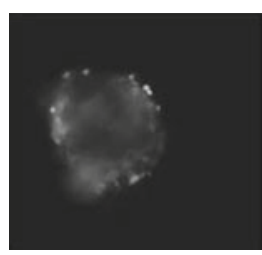

SAL

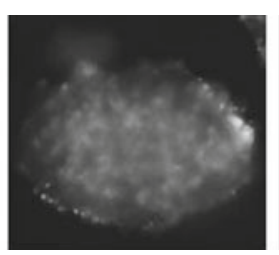

HG

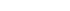

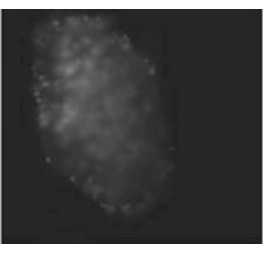

$H G+P B A$

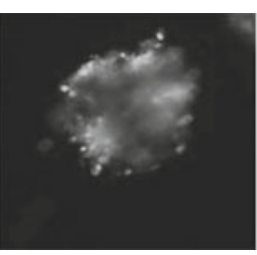

HG

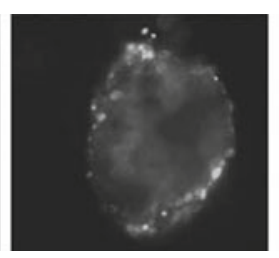

$\mathrm{HG}+\mathrm{PBA}$

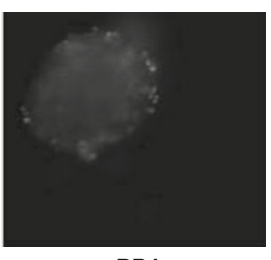

PBA

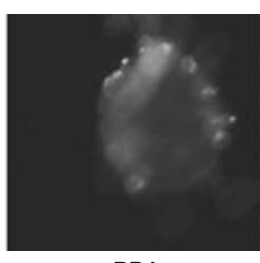

PBA
Fig. 6 Effects of hyperglycaemia and PBA on total and mitochondrial superoxide levels in freshly isolated islets. Animals were treated as described in the legend of Fig. 4 and islets were isolated. Following $1 \mathrm{~h}$ pre-incubation at $37^{\circ} \mathrm{C}$ in $\mathrm{KRBH}$ buffer containing either $2.8 \mathrm{mmol} / \mathrm{l}$ or $20 \mathrm{mmol} / 1$ glucose (for glucose-infused groups), islets were incubated with hydroethidine $(3 \mu \mathrm{mol} / \mathrm{l})(\mathbf{a}, \mathbf{b})$ or MitoSOX $(5 \mu \mathrm{mol} / \mathrm{l})(\mathbf{c}, \mathbf{d})$, in $\mathrm{KRBH}$ buffer containing $2.8 \mathrm{mmol} / \mathrm{l}$ glucose for $15 \mathrm{~min}$ at $37^{\circ} \mathrm{C}$. After

phospho-eIF $2 \alpha$ was not increased but tended to be decreased by $\mathrm{HG}$, as previously found (glucose induces dephosphorylation of eIF2 $\alpha$ [30]). EIF2 $\alpha$ is not only phosphorylated by PERK, but also by other known kinases activated, for example, under conditions of viral infection, amino acid deprivation or haem deficiency [4, 31, 32]. Although these conditions have little or no relevance to our model, additional, as yet unidentified, kinases may phosphorylate eIF2 $\alpha$ in response to oxidative stress (perhaps independently of ER stress) as part of the integrated stress response (ISR) [32]; thus, the increase in phospho-eIF $2 \alpha$ and Chop mRNA may be due to the ISR rather than the UPR as a result of the oxidative stress associated with hyperglycaemia. However, the robust activation of Xbpl splicing (reflective of IRE-1 activation by the UPR) indicates that hyperglycaemia does induce ER stress in pancreatic beta cells. Furthermore, $96 \mathrm{~h}$ hyperglycaemia at $15 \mathrm{mmol} / 1$ did not affect the ISR, based on our eIF $2 \alpha$ results, but induced $X b p l$ splicing. Findings similar to ours, which show a differential ISR response to different glucose concentrations but a progressive induction of the UPR by raising the glucose concentrations, have been reported previously [4].

Our conclusions regarding the involvement of ER stress in glucose-induced beta cell dysfunction are strengthened by the results obtained with TUDCA, another chemical chaperone, which also restored beta cell function. washing with $\mathrm{KRBH}$, islet fluorescence was measured at $550 \mathrm{~nm}$ excitation and $660 \mathrm{~nm}$ emission using an Olympus fluorescence BX51W1 microscope. Approximately 20 islets were measured in each rat (SAL, $n=9 ; \mathrm{HG}, n=9 ; \mathrm{HG}+\mathrm{PBA}, n=8$; PBA, $n=7$ ). Data are expressed as $\%$ of SAL \pm SE (an SAL control rat was studied on each experiment day). ${ }^{*} p<0.05$ and $* * p<0.01$ vs SAL. b and $\mathbf{d}$ show representative images with hydroethidine and MitoSOX, respectively

One limitation of the $48 \mathrm{~h} \mathrm{HG}$ in vivo model is that it is very extreme and short term, and may not represent glucotoxicity in humans. However, glucose-induced beta cell dysfunction does occur in humans exposed to hyperglycaemia ( $\sim 13 \mathrm{mmol} / \mathrm{l})$ for $68 \mathrm{~h}$ [33]. Experimental hyperglycaemia due to prolonged glucose infusion is not well tolerated by humans [34], therefore mechanistic studies need to be performed in animals. Previously, we have shown that TPO prevents glucose-induced beta cell dysfunction following $96 \mathrm{~h}$ hyperglycaemia $(15 \mathrm{mmol} / \mathrm{l})$ in rats [10]. In this present study, we show that PBA is also effective in this model, suggesting that ER stress does play a role in a milder and more chronic model of glucose-induced beta cell dysfunction.

ER stress can impair beta cell function by a number of mechanisms. ER stress can activate PERK to decrease insulin biosynthesis at the level of translation via eIF $2 \alpha$ phosphorylation. However, we do not believe this is likely in our model because at $48 \mathrm{~h}$, PBA prevented beta cell dysfunction without preventing the HG-induced increase in phosphoeIF $2 \alpha$, and because at $96 \mathrm{~h}$, hyperglycaemia did not increase phospho-eIF $2 \alpha$ levels. Another possibility is that activation of the UPR leads to activation of c-jun N-terminal kinase (JNK) [35], which can impair insulin gene transcription via pancreatic duodenal homeobox 1 (PDX-1) nuclear exclusion [36] resulting in impaired insulin biosynthesis, and/or 
a

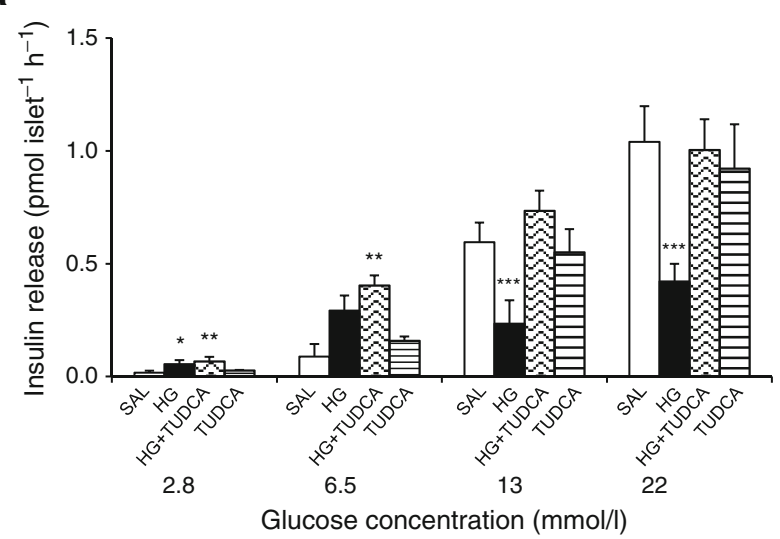

b
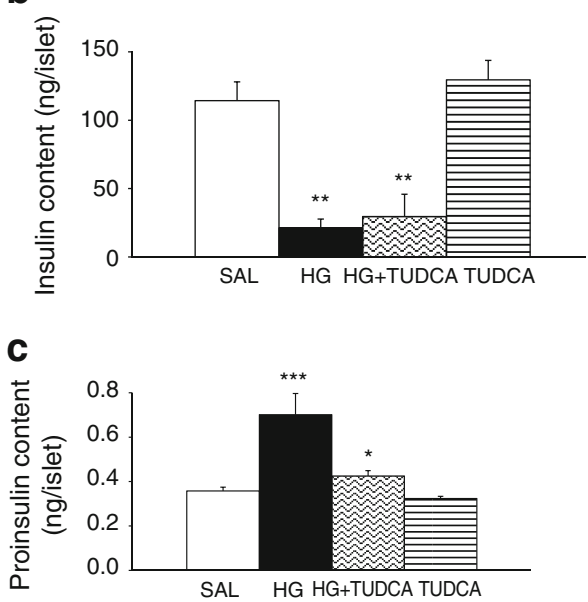

Fig. 7 TUDCA prevents glucose-induced beta cell dysfunction ex vivo. Rats were treated for $48 \mathrm{~h}$ with: SAL; HG; HG + TUDCA, $2 \mu \mathrm{mol} \mathrm{kg}{ }^{-1} \mathrm{~min}^{-1}$; or TUDCA, $2 \mu \mathrm{mol} \mathrm{kg}{ }^{-1} \min ^{-1}$. Following $48 \mathrm{~h}$ infusion, islets were isolated and pre-incubated in KRBH containing $2.8 \mathrm{mmol} / 1$ glucose for $1 \mathrm{~h}$ at $37^{\circ} \mathrm{C}$. Thereafter, five islets of approximately the same size were transferred in triplicate to vials containing fresh medium plus glucose at the following concentrations: 2.8, 6.5, 13 and $22 \mathrm{mmol} / \mathrm{l}$. Islets were incubated for $2 \mathrm{~h}$ at $37^{\circ} \mathrm{C}$, and the insulin released was measured in the supernatant fraction (SAL, $n=7 ; \mathrm{HG}$, $n=7$; HG + TUDCA, $n=6$; TUDCA, $n=4)$ (a). The islet pellets were subjected to acid-ethanol extraction for measurement of insulin content using RIA (SAL, $n=5$; HG, $n=6$; HG + TUDCA, $n=5$; TUDCA, $n=4$ ) (b) and proinsulin content using ELISA (SAL, $n=4$; $\mathrm{HG}, n=4$; $\mathrm{HG}+$ TUDCA, $n=3$; TUDCA, $n=3$ ) (c). Data are means \pm SE. ${ }^{*} p<0.05$, $* * p<0.01$ and $* * * p<0.001$ vs SAL

can directly impair insulin biosynthesis at the level of translation [37]. Indeed, we found that $48 \mathrm{~h}$ hyperglycaemia tended to reduce preproinsulin mRNA which was restored by TUDCA (ESM Fig. 2c) but that neither PBA nor TUDCA attenuated the hyperglycaemia-induced marked impairment in insulin content, suggesting little effect of chemical chaperones on insulin biosynthesis at $48 \mathrm{~h}$. In addition to the impairment of insulin biosynthesis, ER stress can induce mitochondrial superoxide production, which can impair glucose oxidation [38] and activate uncoupling protein 2 (UCP2) [39] to decrease ATP production, and hence insulin granule exocytosis. Thus, it is likely that with extreme short-term hyperglycaemia (48 h model), alleviation of ER stress mainly improves beta cell function at the level of glucose-induced exocytosis as a result of reduced mitochondrial superoxide and improved mitochondrial function rather than at the level of insulin biosynthesis. Interestingly, following $96 \mathrm{~h}$ infusion, PBA partially prevented the decrease in insulin content, and increased islet proinsulin content. Thus, with milder, more prolonged hyperglycaemia ( $96 \mathrm{~h}$ ), alleviation of ER stress may eventually improve insulin biosynthesis, perhaps as a result of transcriptional effects that will have to be further addressed in future studies.

Co-infusion of PBA also prevented glucose-induced beta cell dysfunction in vivo, as assessed by the DI (an in vivo measure of beta cell function, including the beta cell ability to compensate for insulin resistance). PBA tended to improve insulin sensitivity. Insulin sensitivity during a hyperglycaemic clamp mainly reflects peripheral insulin sensitivity because glucose production is totally suppressed by glucose and high insulin. It has been previously reported that PBA reduces obesity-induced ER stress and consequently improves insulin sensitivity in the liver [40]. We have shown that PBA partially prevents the glucose-induced decrease in insulin clearance (as indicated by the C-peptide to insulin ratio). Insulin clearance is mainly a liver function, and is generally proportional to hepatic insulin sensitivity. Thus, PBA may prevent glucose-induced hepatic insulin resistance. As PBA can increase insulin clearance, it cannot be excluded that in vivo this stimulates beta cell compensation for insulin resistance, thus contributing to improved beta cell function. Nevertheless, data from freshly isolated islets clearly show an effect of PBA on insulin secretion.

Following $48 \mathrm{~h}$ high glucose exposure, increased insulin secretion was observed at basal $(6.5 \mathrm{mmol} / \mathrm{l})$ glucose in vivo, and in isolated islets, and this was not affected by TPO or PBA. This increase was not observed in islets at $2.8 \mathrm{mmol} / \mathrm{l}$ glucose, which suggests that it is likely not to be due to islet hypertrophy, which we have previously shown after $48 \mathrm{~h}$ glucose infusion [10], but to a shift in the sensitivity of the beta cell to glucose, possibly due to induction $[41,42]$ and/or increased activity of glycolytic genes as previously shown in a glucose-infusion model [42].

Previously, we reported that $48 \mathrm{~h}$ hyperglycaemia does not increase islet cell apoptosis or affect viability [10]. Thus, these findings suggest that our $48 \mathrm{~h}$ model is mainly a model of glucose-induced beta cell dysfunction rather than loss [10]. However, in the present study, with 48 h hyperglycaemia, an increase in Chop mRNA was observed. This effect was modest and both TPO and PBA prevented this increase. These findings warrant the investigation of glucose-induced beta cell loss in more chronic models of glucotoxicity. We have attempted to measure CHOP protein by western blotting and immunohistochemistry, but the results were 
a

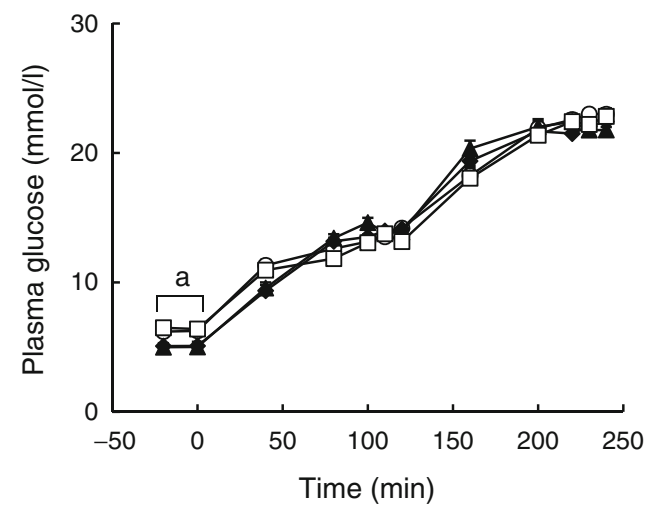

C

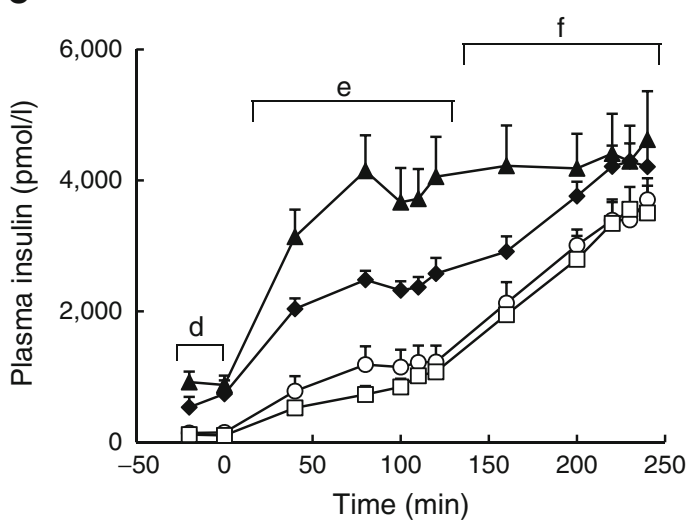

e

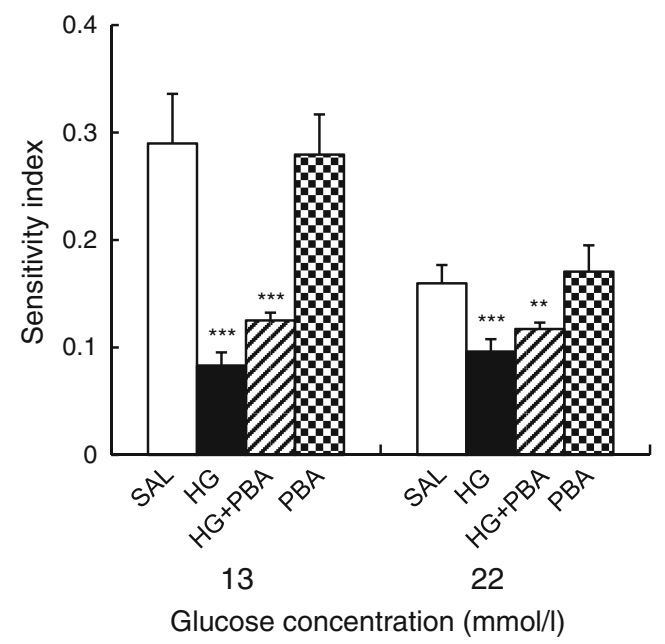

Fig. 8 PBA prevents glucose-induced beta cell dysfunction in vivo during a two-step hyperglycaemic clamp. The groups are described in the legend of Fig. 4. At time $=0$, an infusion of $37.5 \%$ glucose was started. Plasma glucose was maintained at $13 \mathrm{mmol} / \mathrm{l}$ by adjusting the rate of glucose infusion according to frequent $(5-10 \mathrm{~min})$ glycaemic determinations. At $120 \mathrm{~min}$, the glucose infusion was further raised to $22 \mathrm{mmol} / \mathrm{l}$ until the end of the experiment $(\mathrm{time}=240 \mathrm{~min})$. Samples for insulin and C-peptide were taken at regular intervals. a Plasma glucose levels; b Ginf; c plasma insulin; d plasma C-peptide; e

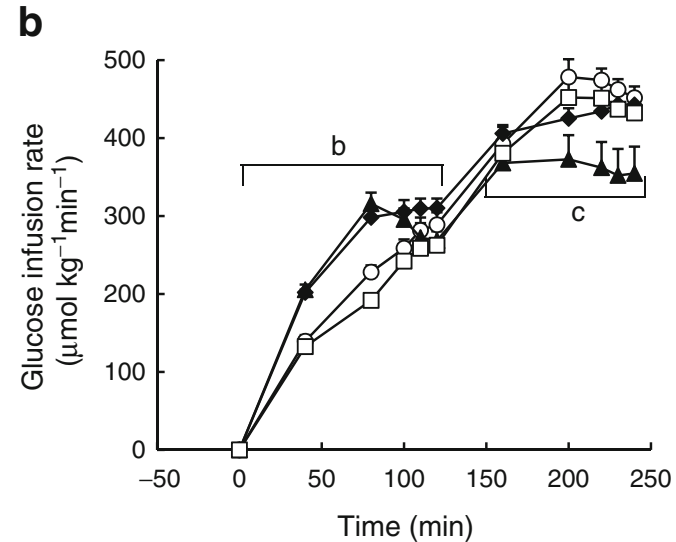

d

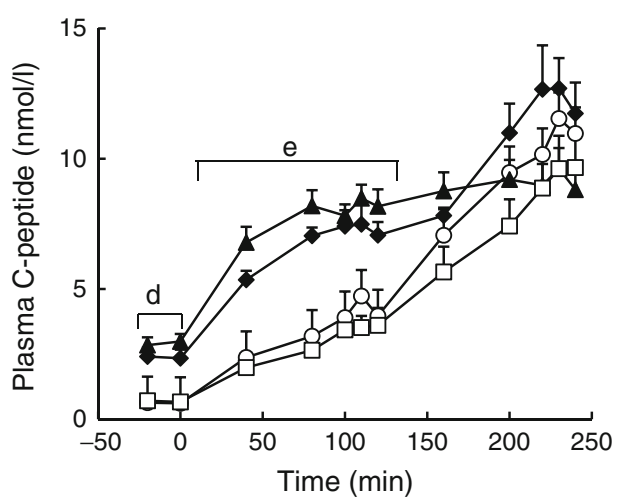

f

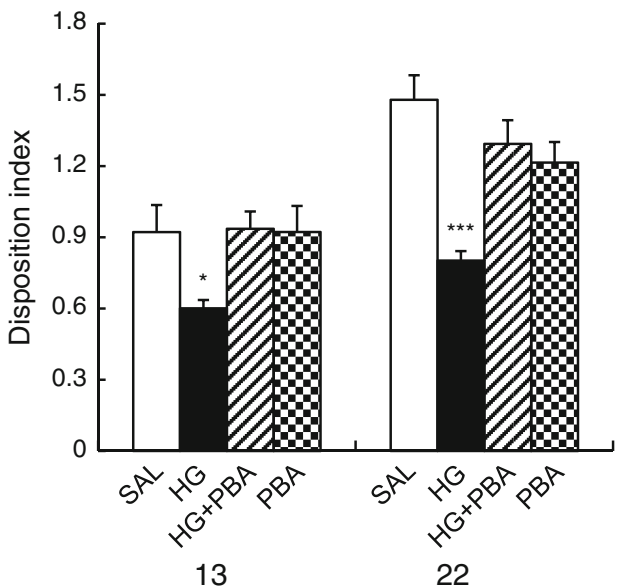

Glucose concentration (mmol/l)

sensitivity index $(\mathrm{M} / \mathrm{I}$ index $=$ Ginf/insulin $)$; and $\mathbf{f}$ disposition index (C-peptide $\times \mathrm{M} / \mathrm{I}$ index), during the two-step hyperglycaemic clamp (SAL, $n=12$; HG, $n=8$; HG + PBA, $n=10$; PBA, $n=8$ ). Data are means \pm SE. ${ }^{a} p<0.01 \mathrm{HG}$ vs SAL, $p<0.001 \mathrm{HG}+\mathrm{PBA}$ vs SAL at basal; ${ }^{\mathrm{b}} p<0.05 \mathrm{HG}+\mathrm{PBA}$ vs SAL at $13 \mathrm{mmol} / \mathrm{l} ;{ }^{\mathrm{c}} p<0.05 \mathrm{HG}$ vs SAL at $22 \mathrm{mmol} / 1 ;{ }^{\mathrm{d}} p<0.001 \mathrm{HG}, \mathrm{HG}+\mathrm{PBA}$ vs SAL at basal; ${ }^{\mathrm{e}} p<0.001 \mathrm{HG}$, $\mathrm{HG}+\mathrm{PBA}$ vs SAL at $13 \mathrm{mmol} / \mathrm{l} ;{ }^{\mathrm{f}} p<0.05 \mathrm{HG}$ vs SAL at $22 \mathrm{mmol} / \mathrm{l}$. ${ }^{*} p<0.05,{ }^{* *} p<0.01$ and ${ }^{* * *} p<0.001$ vs SAL. a-d: SAL, white circles; HG, black triangles; HG + PBA, black diamonds; PBA, white squares 
a

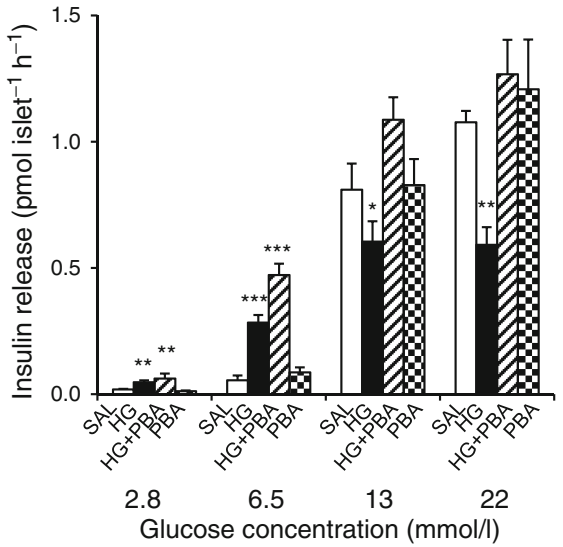

C

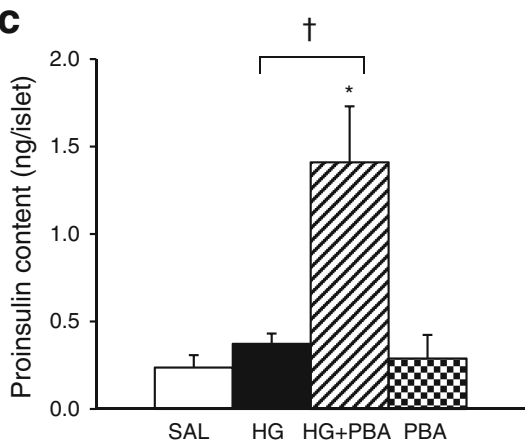

f

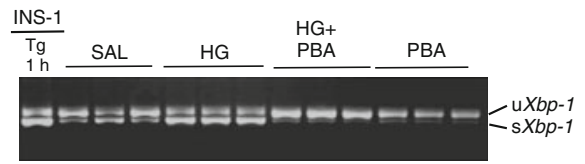

b

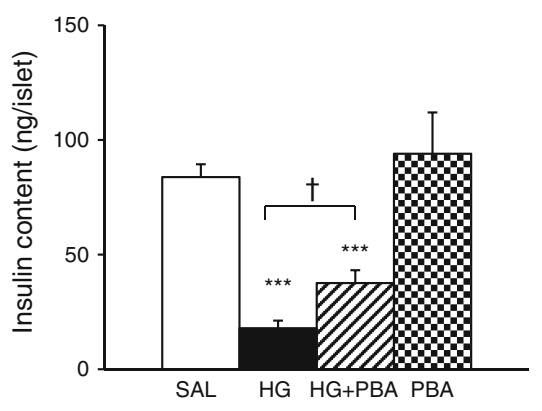

d

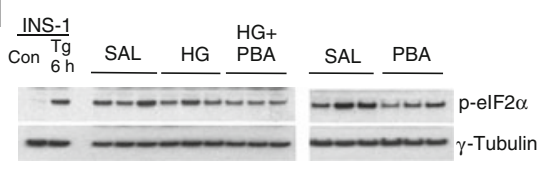

e
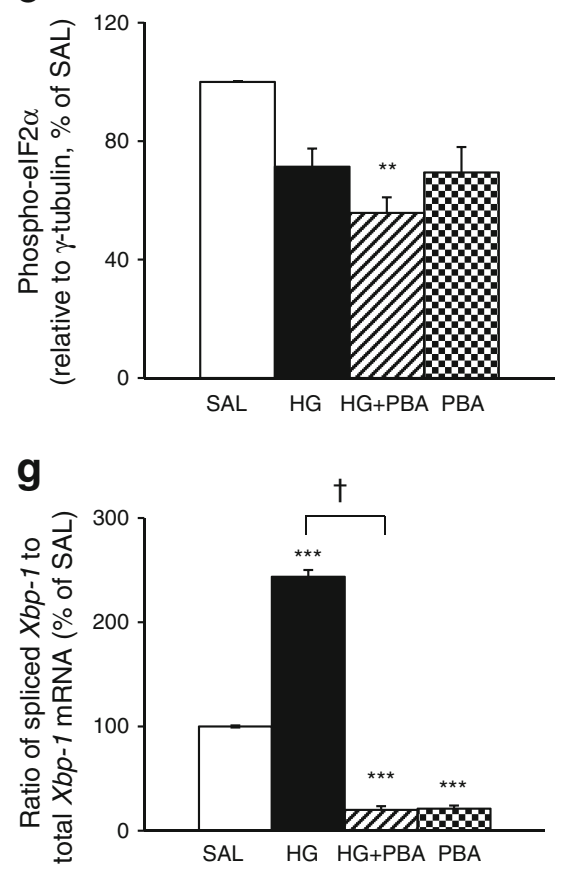

PBA, $n=3$ ) (c). d A representative immunoblot of phospho-eIF2 $\alpha$ (an indicator of PERK activation). Each lane represents islet lysates from one animal. As a positive control, cultured INS-1 cells were treated or not with thapsigargin for $6 \mathrm{~h}$. Western blots for phospho-eIF $2 \alpha$ were quantified and results are expressed as $\%$ of SAL normalised by $\gamma$-tubulin (e) (SAL, $n=4$; HG, $n=3 ; \mathrm{HG}+\mathrm{PBA}, n=3$; PBA, $n=3)$. $\mathbf{f} X b p 1$ mRNA was reverse transcribed and $\mathrm{u} X b p 1$ and $\mathrm{s} X b p 1$ were amplified by real-time PCR using primers that flank the intron excised by IRE-1 endoribonuclease activity. Each lane represents islet lysates from one animal. As a positive control, cultured INS-1 cells were treated with thapsigargin for $1 \mathrm{~h}$. $\mathrm{g}$ The mean of the ratio of $\mathrm{X} X b p 1$ to total $X b p 1 \mathrm{mRNA}$ (as a \% of SAL; SAL, $n=3 ; \mathrm{HG}$, $n=5$; HG + PBA, $n=4$; PBA, $n=3$ ). Data are means \pm SE. ${ }^{*} p<0.05$, ${ }^{* *} p<0.01$ and $* * * p<0.001$ vs SAL; ${ }^{\dagger} p<0.05 \mathrm{HG}+\mathrm{PBA}$ vs HG. Con, control; $\mathrm{Tg}$, thapsigargin

protein elevation or apoptosis, one may argue that glucose may not induce ER stress, but perhaps non-specific variable due to the well-known specificity problem of the CHOP antibody [43]. In the absence of demonstrated CHOP 
upregulation of the UPR. However, we have recently been able to show increased levels of polyubiquinated proteins in islets of HG-treated rats that are characteristic of misfolded and/or aggregated proteins (ESM Fig. 3). The role of hyperglycaemia in inducing ER stress can also be questioned because ER stress-induced CHOP production is not increased in the pancreas of type 1 diabetic individuals [44]. However, it should be considered that: (1) the role of ER stress in beta cell dysfunction and death in type 1 diabetes is minor in comparison with the role of cytokines, whereas their roles are reversed in the glucose infusion model; and (2) type 1 diabetic individuals are treated with insulin (beta cell rest), in contrast to beta cell overstimulation in glucose-infused rats. Regarding overstimulation in response to insulin resistance, Huang et al. have shown greater perinuclear CHOP in the pancreases of obese individuals [44], and greater nuclear CHOP in individuals with type 2 diabetes where ER stress may result from a combination of insulin overstimulation and hyperglycaemia.

In conclusion, our study suggests that ER stress plays a causal role in glucose-induced beta cell dysfunction in vivo, and that there is a reciprocal link between oxidative stress and ER stress in glucose-induced beta cell dysfunction in vivo. Furthermore, this study suggests that chemical chaperones are of potential interest to preserve beta cell function in type 2 diabetes.

Acknowledgements The authors thank L. Lam (Department of Physiology, University of Toronto) for her excellent technical assistance.

Funding This work was supported by Canadian Institutes of Health Research grants MOP-69018 (A. Giacca) and MOP-86641 (A. Volchuk). C. Tang was supported by Scholarships from the Banting and Best Diabetes Centre (University of Toronto), Ontario Graduate Scholarship, and the Canada Graduate Scholarship (Canadian Institutes of Health Research).

Contribution statement CT researched and analysed data and drafted the manuscript. KK researched and analysed data and contributed to revising and editing the manuscript. IS, LZ, TD, AI and PW researched and analysed data and contributed to revising the manuscript. CR-D, MBW and $\mathrm{BM}$ contributed to data analysis and revision of the manuscript. AV contributed to the design of the study and to the discussion, and reviewed and edited the manuscript. AG designed the study, contributed to the discussion, reviewed and finalised the manuscript. All the authors gave final approval to the submission of the manuscript.

Duality of interest The authors declare that there is no duality of interest associated with this manuscript.

\section{References}

1. Robertson RP (2004) Chronic oxidative stress as a central mechanism for glucose toxicity in pancreatic islet beta cells in diabetes. J Biol Chem 279:42351-42354
2. Zhang K, Kaufman RJ (2008) From endoplasmic-reticulum stress to the inflammatory response. Nature 454:455-462

3. Wang H, Kouri G, Wollheim CB (2005) ER stress and SREBP-1 activation are implicated in beta-cell glucolipotoxicity. J Cell Sci 118:3905-3915

4. Elouil H, Bensellam M, Guiot Y et al (2007) Acute nutrient regulation of the unfolded protein response and integrated stress response in cultured rat pancreatic islets. Diabetologia 50:1442-1452

5. Lipson KL, Fonseca SG, Ishigaki S et al (2006) Regulation of insulin biosynthesis in pancreatic beta cells by an endoplasmic reticulum-resident protein kinase IRE1. Cell Metab 4:245-254

6. Hou ZQ, Li HL, Gao L, Pan L, Zhao JJ, Li GW (2008) Involvement of chronic stresses in rat islet and INS-1 cell glucotoxicity induced by intermittent high glucose. Mol Cell Endocrinol 291:71-78

7. Qiu Y, Mao T, Zhang Y et al. A crucial role for RACK1 in the regulation of glucose-stimulated IRE1alpha activation in pancreatic beta cells. Sci Signal 3 (106): ra7

8. Cunha DA, Hekerman P, Ladriere L et al (2008) Initiation and execution of lipotoxic ER stress in pancreatic beta-cells. J Cell Sci 121:2308-2318

9. Zhang L, Lai E, Teodoro T, Volchuk A (2009) GRP78, but not protein-disulfide isomerase, partially reverses hyperglycaemiainduced inhibition of insulin synthesis and secretion in pancreatic $\beta$ cells. J Biol Chem 284:5289-5298

10. Tang C, Han P, Oprescu AI et al (2007) Evidence for a role of superoxide generation in glucose-induced beta-cell dysfunction in vivo. Diabetes 56:2722-2731

11. Laybutt DR, Preston AM, Akerfeldt MC et al (2007) Endoplasmic reticulum stress contributes to beta cell apoptosis in type 2 diabetes. Diabetologia 50:752-763

12. Del Guerra S, Lupi R, Marselli L et al (2005) Functional and molecular defects of pancreatic islets in human type 2 diabetes. Diabetes 54:727-735

13. Back SH, Scheuner D, Han J et al (2009) Translation attenuation through eIF2alpha phosphorylation prevents oxidative stress and maintains the differentiated state in beta cells. Cell Metab 10:1326

14. Song B, Scheuner D, Ron D, Pennathur S, Kaufman RJ (2008) Chop deletion reduces oxidative stress, improves beta cell function, and promotes cell survival in multiple mouse models of diabetes. J Clin Invest 118:3378-3389

15. Carducci MA, Gilbert J, Bowling MK et al (2001) A Phase I clinical and pharmacological evaluation of sodium phenylbutyrate on an 120-h infusion schedule. Clin Cancer Res 7:3047-3055

16. Welch WJ, Brown CR (1996) Influence of molecular and chemical chaperones on protein folding. Cell Stress Chaperones 1:109-115

17. Hertl M, Hertl MC, Malago M, Broelsch CE (1999) In vivo protection of the pig liver against ischemia/reperfusion injury by tauroursodeoxycholate. Langenbecks Arch Surg 384:461-466

18. Kaniuk NA, Kiraly M, Bates H, Vranic M, Volchuk A, Brumell JH (2007) Ubiquitinated-protein aggregates form in pancreatic betacells during diabetes-induced oxidative stress and are regulated by autophagy. Diabetes 56:930-939

19. Asfari M, Janjic D, Meda P, Li G, Halban PA, Wollheim CB (1992) Establishment of 2-mercaptoethanol-dependent differentiated insulin-secreting cell lines. Endocrinology 130:167-178

20. Lai E, Teodoro T, Volchuk A (2007) Endoplasmic reticulum stress: signaling the unfolded protein response. Physiology (Bethesda) 22:193-201

21. Ron D, Walter P (2007) Signal integration in the endoplasmic reticulum unfolded protein response. Nat Rev Mol Cell Biol 8:519-529

22. Malhotra JD, Miao H, Zhang K et al (2008) Antioxidants reduce endoplasmic reticulum stress and improve protein secretion. Proc Natl Acad Sci USA 105:18525-18530 
23. Pizzo P, Pozzan T (2007) Mitochondria-endoplasmic reticulum choreography: structure and signaling dynamics. Trends Cell Biol 17:511-517

24. Scheuner D, Kaufman RJ (2008) The unfolded protein response: a pathway that links insulin demand with beta-cell failure and diabetes. Endocr Rev 29:317-333

25. Cardozo AK, Ortis F, Storling J et al (2005) Cytokines downregulate the sarcoendoplasmic reticulum pump $\mathrm{Ca} 2+$ ATPase $2 \mathrm{~b}$ and deplete endoplasmic reticulum $\mathrm{Ca} 2+$, leading to induction of endoplasmic reticulum stress in pancreatic beta-cells. Diabetes 54:452-461

26. Hennige AM, Lembert N, Wahl MA, Ammon HP (2000) Oxidative stress increases potassium efflux from pancreatic islets by depletion of intracellular calcium stores. Free Radic Res 33:507-516

27. Tu BP, Weissman JS (2002) The FAD- and O(2)-dependent reaction cycle of Ero1-mediated oxidative protein folding in the endoplasmic reticulum. Mol Cell 10:983-994

28. Gorlach A, Klappa P, Kietzmann T (2006) The endoplasmic reticulum: folding, calcium homeostasis, signaling, and redox control. Antioxid Redox Signal 8:1391-1418

29. Rutkowski DT, Arnold SM, Miller CN et al (2006) Adaptation to ER stress is mediated by differential stabilities of pro-survival and pro-apoptotic mRNAs and proteins. PLoS Biol 4:e374

30. Zhang P, McGrath B, Li S et al (2002) The PERK eukaryotic initiation factor 2 alpha kinase is required for the development of the skeletal system, postnatal growth, and the function and viability of the pancreas. Mol Cell Biol 22:3864-3874

31. Ma Y, Hendershot LM (2004) Herp is dually regulated by both the endoplasmic reticulum stress-specific branch of the unfolded protein response and a branch that is shared with other cellular stress pathways. J Biol Chem 279:13792-13799

32. Harding HP, Zhang Y, Zeng $H$ et al (2003) An integrated stress response regulates amino acid metabolism and resistance to oxidative stress. Mol Cell 11:619-633

33. Boden G, Ruiz J, Kim CJ, Chen X (1996) Effects of prolonged glucose infusion on insulin secretion, clearance, and action in normal subjects. Am J Physiol 270:E251-E258

34. Giacca A, Xiao C, Oprescu AI, Carpentier AC, Lewis GF (2011) Lipid-induced pancreatic beta-cell dysfunction: focus on in vivo studies. Am J Physiol Endocrinol Metab 300:E255-E262
35. Urano F, Wang X, Bertolotti A et al (2000) Coupling of stress in the ER to activation of JNK protein kinases by transmembrane protein kinase IRE1. Science 287:664-666

36. Kaneto H, Xu G, Fujii N, Kim S, Bonner-Weir S, Weir GC (2002) Involvement of c-Jun N-terminal kinase in oxidative stressmediated suppression of insulin gene expression. J Biol Chem 277:30010-30018

37. Andreozzi F, D'Alessandris C, Federici M et al (2004) Activation of the hexosamine pathway leads to phosphorylation of insulin receptor substrate-1 on Ser307 and Ser612 and impairs the phosphatidylinositol 3-kinase/Akt/mammalian target of rapamycin insulin biosynthetic pathway in RIN pancreatic beta-cells. Endocrinology 145:2845-2857

38. Miwa I, Ichimura N, Sugiura M, Hamada Y, Taniguchi S (2000) Inhibition of glucose-induced insulin secretion by 4-hydroxy-2nonenal and other lipid peroxidation products. Endocrinology 141:2767-2772

39. Krauss S, Zhang CY, Scorrano L et al (2003) Superoxide-mediated activation of uncoupling protein 2 causes pancreatic beta cell dysfunction. J Clin Invest 112:1831-1842

40. Ozcan U, Yilmaz E, Ozcan L et al (2006) Chemical chaperones reduce ER stress and restore glucose homeostasis in a mouse model of type 2 diabetes. Science 313:1137-1140

41. Roche E, Assimacopoulos-Jeannet F, Witters LA et al (1997) Induction by glucose of genes coding for glycolytic enzymes in a pancreatic beta-cell line (INS-1). J Biol Chem 272:30913098

42. Chen C, Bumbalo L, Leahy JL (1994) Increased catalytic activity of glucokinase in isolated islets from hyperinsulinemic rats. Diabetes 43:684-689

43. Haataja L, Gurlo T, Huang CJ, Butler PC (2008) Many commercially available antibodies for detection of $\mathrm{CHOP}$ expression as a marker of endoplasmic reticulum stress fail specificity evaluation. Cell Biochem Biophys 51:105-107

44. Huang CJ, Lin CY, Haataja L et al (2007) High expression rates of human islet amyloid polypeptide induce endoplasmic reticulum stress mediated beta-cell apoptosis, a characteristic of humans with type 2 but not type 1 diabetes. Diabetes 56:20162027 